INFLUENCE OF THE TEMPERATURE ON GROWTH AND ALKALOID CONTENT OF FIRST-YEAR ATROPA BELLADONNA L.

G. ELZENGA, L. SMEETS and J. W. DE BRUYN 


\title{
INFLUENCE OF THE TEMPERATURE ON GROWTH AND ALKALOID CONTENT OF FIRST-YEAR ATROPA BELLADONNA L.
}

\author{
G. ELZENGA, L. SMEETS and J. W. DE BRUYN \\ Institute of Horticultural Plant Breeding, Wageningen, Netherlands \\ Received 28 Aug. 1956
}

\section{INTRODUCTION}

In breeding Atropa belladonna for high alkaloid content it is of importance to know whether the alkaloid content is affected by the environment. ROMEIKE (4) is of the opinion that environment has only a slight effect on the occurrence, distribution and content of active components in alkaloid containing Solanaceae, as compared with the influence of the genetical constitution. From data obtained from field experiments with Atropa belladonna we gained the same impression. Therefore we tried to ascertain the influence of temperature on growth and alkaloid content of Atropa belladonna.

A preliminary experiment was carried out in 1953, followed by more detailed experiments in 1954 and 1955 . The results were in agreement with each other, so it will suffice to discuss the 1955 experiments only.

\section{MATERIAL AND METHODS}

The experiments were carried out on yellow-flowered Atropa belladonna L. sown on May 13,1955 , at $20^{\circ} \mathrm{C}$. The plants were pricked off into pots on June 9 and 10 . A number of 300 phenotypically identical plants were grown at each of three constant temperatures, viz. $20^{\circ}, 23^{\circ}$ and $26^{\circ} \mathrm{C}$. The experiments were carried out in air-conditioned glasshouses in the phytotron of our Institute (1). The maximum deviation from the mean temperature was about $1{ }^{\circ} \mathrm{C}$. The air humidity was kept at $70 \%$, with a deviation from the mean of about $10 \%$. As the alkaloid content is not constant during the growth of the plants, it was necessary to harvest the plants at each temperature in the same developmental stage (3). The entire aerial part was harvested in the following stages:

$a$. in the vegetative stage when the plants bear about 10 leaves;

$b$. at the moment at which the plants have about 1 or 2 flower buds;

c. when the plants flower and each plant bears 1 or 2 fruits. Pollination had to be carried out by hand, since out-of-doors Atropa belladonna is an insect-pollinated plant;

$d$. in the stage in which the plants flower and bear 6 or 7 fruits per plant.

Harvest was replicated eight times, at each temperature and developmental stage. Five out of eight replicates consisted of nine plants, whereas the remaining three replicates consisted of ten plants each. Consequently a total of 75 plants were gathered in earh harvest at each temperature. As the alkaloid content, even in phenotypically identical plants, may fluctuate considerably, this number of plants and replicates per 


\section{GROWTH AND ALKALOID CONTENT OF ATROPA BELLADONNA L.}

harvest was considered necessary by our statistician to obtain mathematically reliable results.

In each harvest the number of leaves, flower-buds and fruits were counted per plant. In addition the height of each plant was measured whereas weighings were made per replicate. These data were averaged per replicate and then averaged per developmental stage at each temperature.

For a determination of the total alkaloid content the material was cut fine per replicate. After mixing, a sample was dried at $60^{\circ} \mathrm{C}$. The alkaloid content was determined using the method of DiJKSTRA (2).

The results of the experiments have been analysed mathematically.

\section{EXPERIMENTAL RESULTS}

The most favourable temperature for plant development was $23^{\circ} \mathrm{C}$, followed by $26^{\circ}$ and $20^{\circ} \mathrm{C}$. Consequently the developmental stages in which the plants were harvested were reached first at $23^{\circ} \mathrm{C}$, then at $26^{\circ} \mathrm{C}$ and finally at $20^{\circ} \mathrm{C}$. The averages of the data obtained at each temperature in the successive harvests are shown in Table 1.

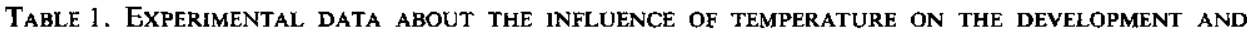
ALKALOID CONTENT OF Atropa belladonna L.

\begin{tabular}{|c|c|c|c|c|c|c|c|c|c|c|}
\hline $\begin{array}{c}\text { Harvest } \\
\text { dates }\end{array}$ & $\begin{array}{c}\text { Average } \\
\text { plant } \\
\text { height } \\
\text { in } \mathrm{cm}\end{array}$ & $\begin{array}{c}\text { Average } \\
\text { number } \\
\text { of } \\
\text { leaves } \\
\text { p. plant }\end{array}$ & $\begin{array}{c}\text { Average } \\
\text { number } \\
\text { of } \\
\text { yellow } \\
\text { leaves } \\
\text { p. plant } \\
\text { (not } \\
\text { weighed) }\end{array}$ & $\begin{array}{l}\text { Average } \\
\text { number } \\
\text { of } \\
\text { flower- } \\
\text { buds } \\
\text { p. plant }\end{array}$ & $\begin{array}{l}\text { Average } \\
\text { number } \\
\text { of } \\
\text { flowers } \\
\text { p. plant }\end{array}$ & $\begin{array}{c}\text { Average } \\
\text { number } \\
\text { of } \\
\text { fruits } \\
\text { p. plant }\end{array}$ & $\begin{array}{c}\text { Mean } \\
\text { fresh } \\
\text { weight } \\
\text { of the } \\
\text { aerial } \\
\text { part } \\
\text { p. plant }\end{array}$ & $\begin{array}{c}\text { Mean } \\
\text { dry } \\
\text { weight } \\
\text { of the } \\
\text { aerial } \\
\text { part } \\
\text { p. plant }\end{array}$ & $\begin{array}{c}\text { Mean } \\
\text { ratio } \\
\text { fresh } \\
\text { dry } \\
\text { weight }\end{array}$ & $\begin{array}{l}\text { Mean \% } \\
\text { of total } \\
\text { alkaloids } \\
\text { in dry } \\
\text { matter }\end{array}$ \\
\hline $20^{\circ} \mathrm{C}$ & & 1 & & & & & & & & \\
\hline $1-8-' 55$ & 8.9 & 11.6 & .- & - & - & - & 15.7 & 1.24 & 12.7 & 0.222 \\
\hline $15-8-' 55$ & 24.5 & 15.6 & 1.2 & 1.8 & - & - & 36.9 & 2.92 & 12.7 & 0.233 \\
\hline $30-8-' 55$ & 52.6 & 20.0 & 4.8 & 10.1 & 1.9 & 2.0 & 70.4 & 6.59 & 10.7 & 0.278 \\
\hline $\begin{array}{l}17-9-' 55 \\
23^{\circ} \mathrm{C}\end{array}$ & 71.2 & 40.7 & 5.4 & 10.1 & 4.7 & 11.4 & 119.9 & 13.75 & 8.8 & 0.300 \\
\hline $25-7-' 55$ & 7.1 & 10.7 & - & - & - & - & 12.1 & 0.92 & 13.1 & 0.231 \\
\hline $10-8-' 55$ & 24.4 & 14.6 & 2.1 & 1.9 & - & - & 36.2 & 3.03 & 12.1 & 0.252 \\
\hline $24-8-' 55$ & 46.7 & 17.8 & 5.0 & 6.6 & 1.4 & 1.6 & 62.0 & 5.70 & 10.9 & 0.297 \\
\hline $\begin{array}{l}10-9-55 \\
26^{\circ} \mathrm{C}\end{array}$ & 74.8 & 41.5 & 5.8 & 15.8 & 6.6 & 14.4 & 119.5 & 13.26 & 9.0 & 0.336 \\
\hline 28-7-'55 & 6.0 & 9.9 & - & - & - & - & 9.7 & 0.76 & 12.8 & 0.235 \\
\hline $12-8-' 55$ & 22.6 & 14.8 & 1.3 & 1.4 & - & - & 33.5 & 2.93 & 11.4 & 0.251 \\
\hline $27-8-' 55$ & 42.9 & 18.1 & 4.8 & 5.5 & 0.8 & 1.5 & 56.5 & 5.37 & 10.5 & 0.288 \\
\hline 14-9-'55 & 71.4 & 40.5 & 5.0 & 26.4 & 6.9 & 13.2 & 110.2 & 11.44 & 9.7 & 0.314 \\
\hline
\end{tabular}

\section{Plant height}

There are distinct differences in plant height between the successive harvests at each temperature (Fig. 1). Moreover it appears that the plants in the first and third harvest are taller at $20^{\circ} \mathrm{C}$ than at $23^{\circ}$ and $26^{\circ} \mathrm{C}$, whereas there is no difference in height between $23^{\circ}$ and $26^{\circ} \mathrm{C}$. Nor are there any differences in height in the second and fourth harvest between $20^{\circ}, 23^{\circ}$ and $26^{\circ} \mathrm{C}$. It should be noted that by differences we mean mathematically reliable differences. 


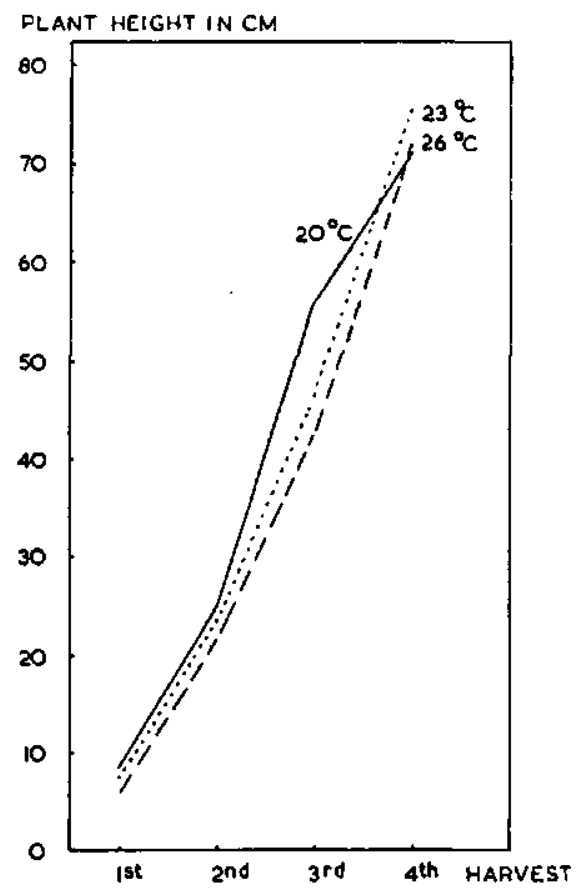

Fig. 1. INFLUENCE OF THE TEMPERATURE ON THE AVERAGE PLANT HEIGHT

In the first and third harvest at $20^{\circ} \mathrm{C}$ the average number of leaves, flower-buds, flowers and fruits was highest, in other words the first and third harvest at $20^{\circ} \mathrm{C}$ were carried out somewhat later than the corresponding harvests at $23^{\circ}$ and $26^{\circ} \mathrm{C}$. This might account for the differences in plant height in the first and third harvest between $20^{\circ} \mathrm{C}$ on the one hand and $23^{\circ}$ and $26^{\circ} \mathrm{C}$ on the other.

\section{Yield of dry matter per plant}

The mean weight of dry matter (Fig. 2) in the first and third harvest is higher at $20^{\circ} \mathrm{C}$ than at $23^{\circ}$ and $26^{\circ} \mathrm{C}$, whereas there are no differences between $23^{\circ}$ and $26^{\circ} \mathrm{C}$. These differences in weight of dry matter may be explained in the same way as those in plant height mentioned above.

In the second harvest there are no differences between $20^{\circ}, 23^{\circ}$ and $26^{\circ} \mathrm{C}$, while in the fourth harvest there were no differences between $20^{\circ}$ and $23^{\circ} \mathrm{C}$ in the mean weight of dry matter, which is clearly lower at $26^{\circ} \mathrm{C}$ than at $20^{\circ}$ and $23^{\circ} \mathrm{C}$.

\section{The mean alkaloid content}

The mean alkaloid content of the dry matter in each harvest at the different temperatures is plotted in Fig. 3. It appears that the alkaloid content increases in the successive harvests at all temperatures. In the first harvest there are no differences in the alkaloid content at the different temperatures. In the second harvest there are no differences between $23^{\circ}$ and $26^{\circ} \mathrm{C}$, while the alkaloid content is clearly lower at $20^{\circ} \mathrm{C}$ than at $23^{\circ}$ and $26^{\circ} \mathrm{C}$. In the third harvest it is higher at $23^{\circ}$ than at $20^{\circ} \mathrm{C}$; there are no differences between $26^{\circ}$ and $23^{\circ}$ or $20^{\circ} \mathrm{C}$. In the fourth harvest there is no difference between $20^{\circ}$ and $26^{\circ} \mathrm{C}$, while the alkaloid content was highest at $23^{\circ} \mathrm{C}$. 


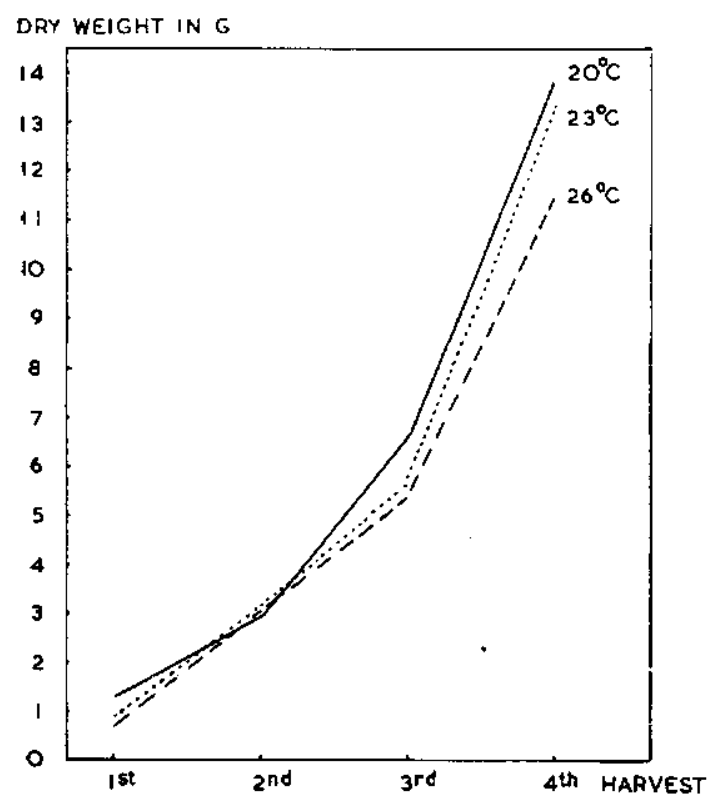

FIG. 2.

INFLUENCE OF THE TEMPERATURE ON THE MEAN DRY WEIGHT OF THE AERIAL. PARTS OF THE PLANTS

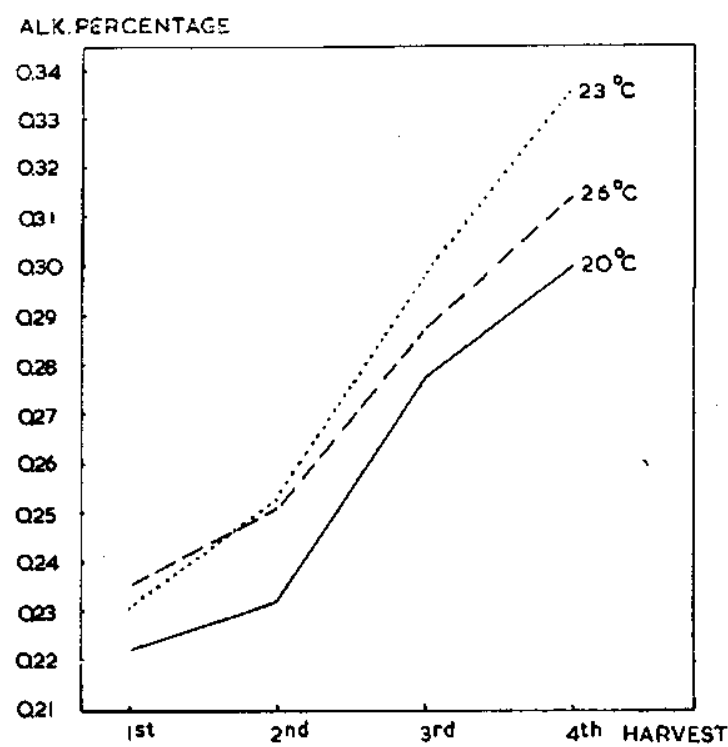

FIG. 3.

INFLUENCE OF THE TEMPERATURE ON THE MEAN ALKALOID PERCENTAGE OF THE AERIAL PARTS OF THE PLANTS

\section{Discussion}

The experiments have shown that the rate of development of Atropa belladonna is influenced by temperature. The most favourable temperature was $23^{\circ} \mathrm{C}$, for at this temperature the successive developmental stages were reached first. Both at $20^{\circ}$ and $26^{\circ} \mathrm{C}$ the plants developed more slowly. At $20^{\circ} \mathrm{C}$ growth was slowest, while temperatures lower than $20^{\circ} \mathrm{C}$ are too low for normal development of Atropa belladonna, as was observed in the preliminary experiment of 1953 . Plant height as well as yield of dry matter in a certain developmental stage are not likely to be influenced by temperature. Consequently in a certain stage of development there is, under the conditions of these experiments, a more or less fixed plant height and weight of dry matter, independent of the temperature at which the plants have been grown.

The alkaloid content increased at all temperatures as the plants developed, the highest content being reached at the temperature at which development was most rapid, i.e. at $23^{\circ} \mathrm{C}$.

The differences in alkaloid content which exist between the different temperatures are of little practical use in growing Atropa belladonna. However, the difference in alkaloid content between the various developmental stages are so great that they should certainly be taken into account in practical growing.

Finally it should be noted that the course of the alkaloid content at the constant temperatures used in the present experiments deviates from the course of the alkaloid 
content in plants grown out of doors, in which this content decreases after flowering or at any rate after the appearance of the first berries (3).

\section{SUMMARY}

In breeding Atropa belladonna for high alkaloid content it is of importance to know whether the alkaloid content is affected by the environment. Therefore some experiments on the influence of temperature were carried out in the phytotron of our Institute. As the results were in agreement with each other only one experiment is discussed in which the influence of three constant temperatures, viz. $20^{\circ}, 23^{\circ}$ and $26^{\circ} \mathrm{C}$, on growth rate, dry matter, and alkaloid content of yellow-flowered Atropa belladonna $\mathbf{L}$. was studied.

It was found that development was quickest at $23^{\circ} \mathrm{C}$, followed by $26^{\circ}$ and $20^{\circ} \mathrm{C}$. Temperature had little or no effect on the height of the plants and weight of dry matter in the corresponding developmental stages. The highest alkaloid content was reached at $23^{\circ} \mathrm{C}$; at $26^{\circ}$ and $20^{\circ} \mathrm{C}$ the alkaloid content was lower. The differences were slight but mathematically reliable.

\section{SAMENVATTING}

Invloed van de temperatuur op de groei en het alkaloïdegehalte van eenjarige Atropa belladonna $L$.

Voor de veredeling van Atropa belladonna op een hoog alkaloïdegehalte is het van belang te weten of de uitwendige omstandigheden invloed uitoefenen op het alkaloidegehalte. Derhalve zijn in het fytotron van ons instituut enkele proeven genomen waarin de invloed van de temperatuur werd bestudeerd. Aangezien de resultaten met elkaar in overeenstemming waren, is volstaan met het weergeven van de uitkomsten van één proef waarin de invloed werd bestudeerd van 3 constante temperaturen $\left(20^{\circ}\right.$, $23^{\circ}$ en $26^{\circ} \mathrm{C}$ ) op de groeisnelheid, het drooggewicht en het alkaloidegehalte van geelbloemige Atropa belladonna L.

Gebleken is dat de ontwikkeling het snelst was bij $23^{\circ} \mathrm{C}$, vervolgens bij $26^{\circ}$ en $20^{\circ} \mathrm{C}$. De temperatuur had weinig of geen invloed op de hoogte van de planten en het gewicht aan droge stof in de overeenkomstige ontwikkelingsstadia. Het hoogste alkaloïdegehalte werd bereikt bij $23^{\circ} \mathrm{C}$; bij $26^{\circ}$ en $20^{\circ} \mathrm{C}$ was het gehalte lager. De verschillen waren gering, doch wiskundig betrouwbaar.

\section{LITERATURE CITED}

1. BraAK, J. P. and Smeets, L., The phytotron of the Institute of Horticultural Plant Breeding at Wageningen, Netherlands. Euphytica 5 (1956): 205-217.

2. Dijkstra, S. P., Verbeterde uitvoering van de door Hegnauer en Flück ontworpen methode voor de snelle bepaling van het alkaloïdengehalte van Solanaceeën-drogerijen. Pharm. Weekbl. 86 (1951): 129-133.

3. ElzenGA, G. and BRuyn, J. W. DE, Interrelation of alkaloid content and stage of development of 1- and 2-year-old Atropa belladonna L. Euphytica 5 (1956): 259-266.

4. Romeike, A., Beiträge zur Chemischen Physiologie der mydriatisch wirkenden Solanaceen - Alkaloïde. Die Pharmazie 8 (1953): 668-674; 729-747. 


\section{VAN HET INSTITUUT MEDEDELINGEN ${ }^{1}$ )}

VAN HET INSTITUUT VOOR DE VEREDELING VAN TUINBOUWGEWASSEN

50. Algemene Veredelingsdagen 1952. Verslag van voordrachten en discussies. Juni 1953 ... . . f 1,50

51. Sneep, J. Practijkproeven met Spitskool 1949-1950 en 1950-1951. Juti 1953 . . . . . . i 0.65

52. Boom, B. K. Internationaal reglement voor de naamgeving van sekweekte planten - O Darretsen. Opbrengstproeven

53. Kronenberg, H. G. en F. Garretsen. Opbrengstproeven met aardbeiklonen. November 1953 . Verslag van voordrachten en discussies. December 1953 . . . . . . $f 1,-$

55. Floor, J. Planten in plastic. Januari $1954^{\circ}$. Uitverkocht

56. Banga, 0 . Taproot-problems in the breeding of root vegetables . f 0,25

57. Jensma, J. R, en A. Kraai. Practijkproeven mec Rode Kool 1950-1951. Juni 1954 ........ f1,10

58. Jensma, J. R. en A. Kraaj. Practijkproeven met Spruitkool 1950-1951. Juli 1954. . . . . . f 0,85

59. Veredelingsdag Fruitgewassen 1954. Verslag van voordrachten en discussies. Augustus $1954 \ldots$. . . . f 0,95

60. Kraai, A. The use of Honey-bees and Bumble-bees in breeding work. September $1954 \ldots . .$. f 0.45

61. Jensma, J. R. en A. Kraai. Practijkproeven met Witte Kool 1952-1953. Februari 1955 . . . . . f 1.35

62. Banga, O, en J. W. de Bruyn. Selection of Carrots for Carotene Content. Februari 1955 ...... f 0.25

63. Kronenberg, H. G. en L. M. Wassenaar. Practijkproeven met aardbeirassen 1952-1954. April 19S5 , f0.90

64. Keuls, M. and J. W. Sieben. Two statistical problems in plant selection. April 1955

f 0,35

5. Banga, 0 . The Institute of Horticultural Plant Breeding. April 1955

66. Banga, 0 . Uienveredeling met gebruikmaking yan inteeit en hersel door heterosis. Juni 1955 . ... f 0,30

67. Banga, 0 . Carrot yield analysis. September $1955:$ f 0,30

68. Banga, O., J. W. de Bruyn and L. Smeets. Selection of carrocs for carotene content. II Sub-normal content at low temperature. September 1955

69. Brak, J. P. Effect of temperature and light on Jun 0.25 lows in strawberries. September 1955 f 0,25

70. Banga, $O$. De ontwikkeling van de rassensituatie bij groentegewassen. Oktober $1955 \ldots \ldots$. . . . f 0,25

71. Bruyne, A. S. de. Tendenzen in de ontwikkeling van het Nederlandse fruitsortiment. Oktober 1955 . . . f 0,40

72. Banga, O. Praktijkproeven met Knolselderij 1953-1954. November 1955

73. Floor, J., Proeven met stekken onder waterverneveling. April 1956

74. Andeweg, j. M. en J. H. Ruyter. Praktijkproeven met Tomaten 1954-1955. April 1956

75. Andeweg, J. M. en A. van Steenbergen. Praktijkroe ven met Stoksnijbonen 1953-1954. Mei 1956 . . f 0,35

76. Banga, O. en J. L. van Bennekom. Praktijkproeven met Ronde Wirpunt Radijs 1953-1954. Mei 1956. f 0,55

77. Smeets, $L$. and Hester G. Kronenberg. Runner formation on strawberry plants in autumn and winter.
Smeets, L. Runner formation on strawberry plants in autumn and winter. II. Influence of the light intensity on the photoperiodical behaviour. Juni 1956.. f 0,30

78. Smeets, L. Influence of the temperature on runner production in five strawberry varieties. Juni 1956 . . . f 0,25

79. Smeets, L. and L. M. Wassenaar. Problems ol heat spot in Fragaria vesca $L$. when indexing strawberry selections

80. Banga, $O$. and J. $W$. de Bruyn. Selection of carrots for carotene contenc. III Planting distances and ripening equilibrium of the roots. Juni 1956 ........ f 0,35

81. Banga, $\boldsymbol{O}$. International conference on the improvement and on the standardization of vegetable varieties at Wageningen, Netherlands, on August 26 and 27, 1955 August $1956 \ldots . . . . . . .6$. . . 0,75 82. Floor, J. Proeven met vermeerdering van houtige gewassen. September 1956 . . . . . . f 0,80

3. Gerritsen, C. J. Improvement of the cherry varieties used in the Necherlands. Oktober 1956 ..... 0.35

84. Gerritsen, C.J. Research offered new possibilities for nuc growing in the Netherlands. Oktober 1956. f 0.25

85. Andeweg, J. M. The breeding of scab-resistant frame cucumbers in the Netheriands. Oktoker 1956. . . f0,30

86. Zeilinga, A. E. An improved acetic orcein squash method for serial cytological preparations. Oktober 1956 f 0,20

37. Braak, J.P and L.Smeets, The Phytotron of the institute of Horticuitural Plant Breeding at Wageningen, the $\mathrm{Ne}$ therlands. Oktober 1956.......... f 0,30

88. Banga, $O$, and L. Smeets. Some effects of the photoperiod on growth and pithiness of radish. Oktober 1956. . f 0,30

89. Kho, Y. O and J.P. Braak. Reduction in the yield and viability of carrot seed in relation to the occurence of the plant bug Lygus campestris L. Oktober 1956 . . f 0,35

90. Terpstra, $W$. Some factors influencing the abscission of debladed leaf petioles. Oktober 1956 . . : . f0,35

91. Keuls, M. en J. J. Post. Invloed van de cemperatuur op de groel van asperges. Januari 1957.... . f 0,70

92. Smeets, L. Some effects of the photoperiod on the shoot growth of cherry seedlings. Febr. 1957. . f 0,30

93. Elzenga, G. and J. W. de Bruyn. Interrelation of alkaloid content and stage of development of 1- and 2-year - old - Atropa belladonna L. Febr. 1957 .

94. Elzenga G., L. Smeets and W W. de Bruyn. Influence of the temperature on grawth and alkaloid content of first-year Atropa belladonna L. Februari 1957 f f 0,25 95. Ferguson, J. H. A. Some applications of binomial probability paper in genetic analyses. Februart 1957 . 0,35 96. Jensma, J. R. Teelt en veredeling van bloemkool. Mart 1957. . . . . . . f 3,50

97. Boom, B. K. Benaming, geschiedenis en kenmerken van een aantal houtachtige planten. Nomenclature, history and characteristics of some woody plants. Maart 1957.................. f f 2,50

\section{PERSBERICHTEN UITSLAGEN PRACTIJKPROEVEN}

11- 3-'51. Uitsiag Practijkproeven Westlandse Boerenkool 1949-1950.

3- 9-51. Uitslag Practijkproeven Spitskool 1950-1951.

23- 1-52. Uitsiag Practijkproeven Vroege en Herfst Rodekool 1950-1951.

31- 3-'52. Uitslag Practijkproeven Spruitkool 1950-1951.

4-11.'52. Uitslag Practijkproeven Ronde Rode Radijs 1951-1952.

4-11-'52. Uitslag Practijkproeven Vroege Rijspeulen 1951-1952.

25-11-52. Uitslag Practijkproeven Lange Kroten 1951-1952.

23- 1.53. Uitslag Practijkproeven Radijs Ronr'e Scharlakenrode Extra Kortlool 1951-1952.

13- 5-'53. Uitslag Practijkproeven Bewaar Rode Kool 1951-1952.

10- 9-'53. Uitslag Practijkproeven Vroege Witce Koot 1952-1953.

18-12-'53. Uitslag Practijkproeven Herfst Witte Kool 1952-1953.

3- 6-54. Uitslag Practijkproeven Bewaar Witte Kool 1952-1953.

17-11-'54. Uitslag Practijkproeven Stoksnijbonen 1953-1954.

2-12-'54. Uitslag Practijkproeven Ronde Rode Witpunt Radijs 1953-1954.

12- 2-'55. Uitslag Practijkproeven Knolselderij 1953-1954.

1- 9-'55. Uitslag Practijkproeven Vroege Groene Savoye Kool 1954-1955.

14-11.'55. Uitslag Practijkproeven Tomaten 1954-1955.

27 12-55. Uitslag Practijkproeven Witlof yroege trek 1954-1955.

2-3.56. Uitslas Practikproeven Wirlof middelyroege trek 1954-1955.

5-3-'56. Uitslag Practijkproeven Schorseneren 1954-1955.

28- 5-'56. Uitslag Practijkproeven Savoye Kool 1954-1955.

28- 5-'56. Uitslag Practijkproeven Witlof koude kuil en meilof 1954-1955.

30- 7-56. Uitslag Practijkproeven Tuinbonen 1955-1956.

1. 9-'56. Uitsiag Praktijkproeven Amsterdamse Bakwortel 1955-1956

1. 9-'56. Uitslag Praktijkproeyen Vroege Rode Kool 1956

1- 9-'56. Uitslag Praktijkproeven Platronde Kroten 1955-1956

20- 9-'56. Uitslag Praktijkproeven Pronkbonen 1955-1956.

26-11-'56. Uitslag Praktijkproeven Herfstprei 1955-1956.

31- 1-'57. Uitslag Praktijkproeven Winterwortelen 1955-1956.

Zijn geplaatst in diverse tuinbouwbladen 


\section{RASSENLIJSTEN I) \\ UITGEGEVEN DOOR HET INSTITUUT VOOR DE VEREDELING VAN TUINBOUWGEWASSEN}

Achtste Beschrijvende Rassenlijst voor Fruit. 1957. . f 1,75 $\begin{gathered}\text { Negende Beschrijvende Rassenlijst voor Groentegewas- } \\ \text { sen, 1957. Redacteur Dr. O. Banga . . . . . f 1,75 }\end{gathered}$

\section{PUBLIKATIES VAN HET INSTITUUT VOOR DE VEREDELING VAN TUINBOUWGEWASSEN IN ANDERE ORGANEN OF IN BOEKVORM EVENTUEEL IN SAMENWERKING MET ANDERE INSTELLINGEN ${ }^{2}$ )}

De publikaties, waarvan prijs èn uitgever worden vermeld zijn verkrijgbaar in de boekhandel. Overigens wende men zich tor de opgegeven bronnen of tot de bibliotheek van het I.V.T.

Boom, B. K. Cotoneaster wardii en verwante soorten. De Boomkwekerij 11, 1955: 3.

Gerritsen, C. J. Zit er wat in de teelt van hazelnoten? De Fruitceelt 45, 1955: 865

Kronenberg. H. G. Aardbeien. Wat moeten we toch planten? De Fruitteelt 45, 1955: 866-867.

Gerritsen, C. J. Gaat U kersen planten? De Fruitteelt 45 1955 : 909-910.

Burg. J. P. L. L. A. en G. Elzenga. Rapport over een studiereis a angaande de teelt en verwerking van geneeskrachtige en aromatische gewassen in Duitsland en Frankrijk $(16 \mathrm{t} / \mathrm{m}$ 31 augustus 1955). V.N.K.-Nieuws, september 1955: 92-99.

Boom, B. K. Sorbus pratti en S. koeneana. De Boomkwekeri 11, 1955: 27.

Elzenga G. Het rooien van de wortels van Angelica en Valeriaan. V.N.K.-Nieuws, november 1955: 110-111

Elzenga, $\boldsymbol{G}$. Pepermunt opnieuw inplanten. V.N.K.-Nieuws, november 1955 : 112.

Boom, B. K. Vraagstukken rondom het Cotoneaster-sortiment, De Boomkwekerij 11, 1955, 41-42.

Jensma, J. R. Rassenkeuze bij bloemkool. Groenten en Fruit 11, 1956: 721.

Bruyne, A. S. de. Nieuwe appelrassen tot James Grieve. De Fruitwereld 1, 1956; no 4; 8-9.

Boom, B. K. Cercidiphyilum. De Boomkwekerij 11, 1955: 27.

Broertjes, C. Reactie op vraagstukken rondom het Cotoneastersorziment. De Boomkwekerij 11, 1956: 67-68.

Broertjes, C. Veredeling op ziekteresistentie bij rozen, De Boomkwekerij 11, 1956: 73 .

Boom, B. K. Acer platanoides, reitenbach' en ,rubrum De Boomkwekerij 11, 1956: 74.

Bruyn, J.W. de. De exportcontrole van kruiden in 1955 V.N.K.-Nieuws, januari 1956: 134-135.

Boom, B. K. Buxus, buksus of buks. De Boomkwekerij 11 1956: $80-81$.

Boom, B. K. Drie nieuwe wilgen. De Boomkwekerij 11, 1956: 81-82.

Boom, B. K. Enkele bontbladige bomen, De Boomkwekeri 11, 1956: 88 .

Boom, B. K. Een nieuwe monographie over het geslacht Philadelphus. De Boomkwekerij 11, 1956: 96-97.

Gerritsen, C. J. Zal de noot een deugd worden? De Fruitwereld 1, 1956; no. 14: 5 .

Banga, 0 . Enkele opmerkingen naar aanleiding van een internationale conferentie: Zaadbelangen 10, 1956: 101-102.

Kronenberg, H. G. Strawberry growing in the Netherlands. American Fruit Grower 76, 1956; no. 4: 77.

Elzenga, G. Lobelia inflata. V.N.K.-Nieuws, maart 1956: 163 166.

Boom, B. K. Variëteit en cultivar. De Boomkwekerij $\{$ 1, 1956 112-113.

Andeweg, J. M. Vroegrijpende moneymaker's. Zaadbelangen 10, 1956: 145 .

Boom, B. K. Verwarring over de plantennamen. Vakblad voor de Bloemisterij 11, 1956: 130-131.

Gijsbers, J. W. Ruimtebesparing bij de opberging van dia's en negatieven. Meded. Dir. Tuinbouw 19, 1956: 298-300

Boom, B. K. Over een verzameling prijscouranten. De Boomkwekerij 11, 1956: 128-129.

Boom, B. K. Een Amerikaan over Boskoop. De Boomkwekerij 11, 1956: 130 .
Huyskes, J. A. Klauwenselectie bij asperges geeft goed resultaten. Boer en Tuinder (Land en Vee) 10, 1956: no. $482: 17$

Koot, Y. Y. en J. M. Andeweg. De groenteteelt in Amerika. 's-Gravenhage, C.O.P., 1956. 149 blz. f 7,00.

Banga, 0 . Kweker en overheid in de sector groentezaden. Zadbelangen 10, 1956: 189-190.

Kho, $Y$. 0 . Opbrengstvermindering en kiemkrachtverlaging van wortelzaad als gevolg van aancasting door wantsen. Zaadbelangen 10, 1956: 193-194.

Elzenga, G. Digitalis lanata Ehr. V.N.K.-Nieuws 1956: 167-170, 193-199.

Andeweg, J. M. Rationalisatie en rassenkeuze. Groenten en Fruit 12, 1956: 111.

Kho, Y. O.en J. P. Braak. Opbrengstvermindering en kiemkrachtrerlaging van wortelzaad als gevolg van aantasting door wantsen. Meded. Dir. Tuinb. 19, 1956: 440-445.

Kronenberg. H. G. Praktijkproeyen met aardbeien in 1956 De Tuinderij 36, 1956, no 33: 1-3. Groenten en Fruit 12 1956: 177.

Floor, J. en P. A. Wezelenburg. Stekken onder plastic. De Boomkwekerij, 11, 1956: 174-175.

Terpstra, $W$. Some factors influencing the abscission of debladed leaf petioles. Acta Botanica Neerlandica 5, 1956: 157-170

Bruyne, A. S. de. Trends and developments in Dutch varieties. The Commercial Grower 1956, no 3165 : 419-422.

Smeets, L. A note on the shorcening of the juvenile phase in cherry seediings. Euphytica 5, 1956: 117-118.

Boertjes, C. Vorstschade aan Rhododendronvariëceiten in in 1956. De Boomkwekerij 11, 1956: 187-189.

Podenburg, C. M. Het kweken van wolfresistente spinazierassen. Zaadbelangen 10, 1956: 325-326.

Andeweg, J. M. Een waardevolle vroege kruisingsouder. Zaadbelangen 10, 1956: 344

Huyskes, J. A. en C. M. Rodenburg. Internationale samenwerking bij het onderzoek van slarassen. Meded. Dir. Tuinb. 19, 1956: 823:826.

Gerritsen, C. J. De teelt van buitenperziken I, II. IIt, IV. Groenter en Fruit 12, 1956: 537-538; 569-570; 603; 628-629.

Gerritsen, C. 1. De Feyoa, aan nieuw culturgewas? Meded. Dir. Tuinb. 19, 1956: 889-894.

Jensma, J. R. Sluitkoolrassen. Wageningen, I.V.T. 1956: $150 \mathrm{blz}$. f13.50.

Floor, 1. Planten in plastic. Wageningen. I.V.T., 1956. f 0.35

Izenga, G. De teelt van Valeriaan. V.N.K.-Nieuws 4 1956: 234-236.

Elzenga, G. Het mechanisch rooien yan Valeriaan. V.N.K. Nieuws 4, 1956: 246.

Elzenga, G. Het opkweken van plantmateriaal van Levisticum en Rheum. V.N.K.-Nieuws 4, 1956: 246.247.

Elzenga, G. Roest in munt. Zou gier helpen? V.N.K. Nieuws 4, 1956: 247

Elzenga, G. Mechanisch planten van Valeriaan blijkt zeer goed mogelijk. V.N.K.-Nieuws 4, 1956: 248-249.

Elzenga, G. De oogstdatum van Digitalis lanaca. V.N.K.Nieuws 4, 1956: 249-250.

Giessen, A. C. v. d. en A. v. Steenbergen. Een nieuwe methode voor de toetsing van bonen op resistentie tegen vlekziekte. Zaadbelangen 11, 1957: 26-27

1) Zolang de voorraad strekt kunnen deze publikaties franco worden toegezonden, na ontyangst van het vermelde bedrag op giro no. 425340 van het Instituut voor de Veredeling van Tuinbouwgewassen, S. L. Mansholtlaan 15 te Wageningen onder vermelding van wat verlangd wordt; ook bescaat de mogelijkheid deze publikaties uit de bibliotheek van het !.V.T. te lenen.

1) Eerder verschenen publikaties zijn vermeld achterin in de Mededelingen nos $1 \mathrm{t} / \mathrm{m} 89$ 